\title{
Modeling the Risk of Groundwater Contamination using Modified DRASTIC and GIS in Amman-Zerqa Basin, Jordan
}

Research Article

\author{
Abdulla M. Al-Rawabdeh ${ }^{1}$, Nadhir A. Al-Ansari' ${ }^{2 *}$, Ahmed A. Al-Taani ${ }^{3}$, Fadi L. Al-Khateeb ${ }^{4}$, Sven \\ Knutsson² \\ 1 Department of Geomatics Engineering, University of Calgary, Alberta, Canada \\ 2 Department of Civil, Environmental and Natural Resources and Engineering, Lulea University of Technology, Sweden \\ 3 Department of Earth and Environmental Sciences, Faculty of Science, Yarmouk University, Irbid 21163, Jordan \\ 4 Department of Chemistry, University of Calgary, Alberta, Canada
}

Received 27 January 2014; accepted 29 March 2014

\begin{abstract}
Amman-Zerqa Basin (AZB) is the second largest groundwater basin in Jordan with the highest abstraction rate, where more than $28 \%$ of total abstractions in Jordan come from this basin. In view of the extensive reliance on this basin, contamination of AZB groundwater became an alarming issue. This paper develops a Modified DRASTIC model by combining the generic DRASTIC model with land use activities and lineament density for the study area with a new model map that evaluates pollution potential of groundwater resources in AZB to various types of pollution. It involves the comparison of modified DRASTIC model that integrates nitrate loading along with other DRASTIC parameters. In addition, parameters to account for differences in land use and lineaments density were added to the DRASTIC model to reflect their influences on groundwater pollution potential. The DRASTIC model showed only $0.08 \%\left(3 \mathrm{~km}^{2}\right)$ of the AZB is situated in the high vulnerability area and about $30 \%$ of the basin is located in the moderately vulnerable zone (mainly in central basin). After modifying the DRASTIC to account for lineament density, about $87 \%$ of the area was classified as having low pollution potential and no vulnerability class accounts for about $5.01 \%$ of the AZB area. The moderately susceptible zone covers $7.83 \%$ of the basin's total area and the high vulnerability area constitutes $0.13 \%$. The vulnerability map based on land use revealed that about $71 \%$ of the study area has low pollution potential and no vulnerability area accounts for about $0.55 \%$, whereas moderate pollution potential zone covers an area of $28.35 \%$ and the high vulnerability class constitutes $0.11 \%$ of AZB. The final DRASTIC model which combined all DRASTIC models shows that slightly more than $89 \%$ of the study area falls under low pollution risk and about $6 \%$ is considered areas with no vulnerability. The moderate pollution risk potential covers an area of about $4 \%$ of AZB and the high vulnerability class constitutes $0.21 \%$ of the basin. The results also showed that an area of about $1761 \mathrm{~km}^{2}$ of bare soils is of low vulnerability, whereas about $28 \mathrm{~km}^{2}$ is moderately vulnerable. For agriculture and the urban sector, approximately $1472 \mathrm{~km}^{2}$ are located within the low vulnerability zone and about $144 \mathrm{~km}^{2}$ are moderately vulnerable, which together account for about $8 \%$ of the total agriculture and urban area. These areas are contaminated with human activities, particularly from the agriculture. Management of land use must be considered when changing human or agricultural activity patterns in the study area, to reduce groundwater vulnerability in the basin. The results also showed that the wells with the highest nitrate levels $(81-107 \mathrm{mg} / \mathrm{l})$ were located in high vulnerable areas and are attributed to leakage from old sewage water.
\end{abstract}

Keywords: Groundwater • Nitrate $\cdot$ DRASTIC $・$ Amman Zerqa Basin • Jordan

(C) Versita sp. z o.o. 


\section{Introduction}

Groundwater constitutes the largest single source of freshwater in many parts of the world and provides a risk buffer to sustain critical water demands during drought cycles, especially in semi-arid and arid regions [1]. In many parts of Jordan, groundwater provides nearly all of the water supply for drinking and agricultural activities. However, the growing demand for water has placed substantial pressures on water resources. These demands for water continue to rise due rapid population growth and climate change. The increasing gap between the demand for water use and the supply of water has resulted in considerable competition between sectors. In view of the extensive reliance on groundwater resources in Jordan, contamination of groundwater became a widespread issue and poses imminent threats to these resources. Remediation of polluted aquifer resources is always expensive and protracted, and is often abandoned, leading to loss of valuable resources at a considerable economic cost. As the conservation of water resources is critically important for Jordan, groundwater vulnerability studies are increasingly becoming a subject of research [2-8]. Among others, aquifer vulnerability to pollution by the DRASTIC method has been frequently used.

Shirazi et al., [9] compared and assessed literature related to GIS-based DRASTIC method for groundwater vulnerability assessment. The paper compared various groundwater vulnerability assessments methods in order to identify research gaps. It concluded that a modified GIS-based DRASTIC method, compared to a generic DRASTIC model, was able to assess an extensive amount of complex databases and proved to be a good model for groundwater vulnerability assessment in agricultural, arid, semi-arid and basaltic regions. Al-Hallaq and Elaish [10], used the DRASTIC model to assess aquifer layers in order to determine vulnerability assessment of the groundwater contamination in the Khanyounis governorate, Egypt. Al Hallaq used ArcGIS 9.3 software to create a GIS model of the vulnerability assessment and determined that contamination rates increased when low water table levels, vadose zone, were found. Soil media and vadose zones therefore had the greatest impact on assessing groundwater vulnerability. Shamrukh et al., [11], examined the effects of nitrogen and phosphorus chemical fertilizers on groundwater contamination in the Nile valley, Egypt, and used that data to predict trends resulting from future fertilizer uses. The authors determined that phosphorus levels were not yet of concern but that simulation revealed that within 20 years it will exceed guidelines. Low elevation water supplies already exceed drinking water guideline concentrations for nitrogen levels. The paper emphasizes that continuous monitoring and early detection of contamination levels is essential and deep wells can be used as an alternative water supply. Al-Hanbali and Kondoh [12], examined groundwater contamination vulnerability within the Dead Sea groundwater basin, Jordan, using the DRASTIC model and $\mathrm{HAl}$ index. The authors determined that groundwater quality is related to the amount of human activity, proximity to fault and drainage systems, and the impact of the vadose zone, aquifer medium present in the area. The study determined that water table depth and hydraulic conductivity parameters had very little impact on contamination results which were verified using nitrate concentrations provided by the Jordanian ministry of water and irrigation. Jasem and Alraggad [13], emphasized that land use map and detailed environmental impact assessment study of groundwater should be carried out before beginning any project. Examining the land use of an area, based on the contamination risk assessment, is the proposed method used to lower contamination of precious groundwater resources. Contamination assessment for the Azraq basin, Jordan, was examined as the study area and authors used the DRASTIC vulnerability index, examined rainfall, topographic detail, soil permeability, human activities and classified the area into four vulnerability zones. Awawdeh and Jaradat [7], assessed the aquifers vulnerability to contamination in the Yarmouk River basin based on modified DRASTIC method. The general DRASTIC index for groundwater pollution was low in the whole basin, and the pesticide DRASTIC vulnerability map indicated that about $31 \%$ of the basin is classified as having moderate vulnerability, which may be attributed to agricultural activities in the area.

Amman Zerqa Basin (AZB) is a transboundary basin shared between Jordan and Syria, of which about $90 \%$ lies in Jordan. It is home for about $60 \%$ of Jordan's population [14] and hosts about $70 \%$ of Jordan's industrial activities. AZB is subject to extreme and increasing water scarcity, where more than $28 \%$ of total groundwater abstractions in Jordan come from this basin. The geographic location and altitudinal variations of $A Z B$, in a transitional area between the highlands in the west and the desert in the east (Figure 1), makes it of diverse biological communities, land use patterns as well as climatic conditions. The average annual precipitation in the western part of the basin is about $400 \mathrm{~mm}$ and is relatively densely populated, whereas the average annual rainfall in the eastern basin (fully desertic) is about $150 \mathrm{~mm}$ with small communities of Bedouins.

Irrigated cultivation is common in the vicinity of groundwater wells and along the Zerqa River banks, whereas rain-fed agriculture is found in highlands where 


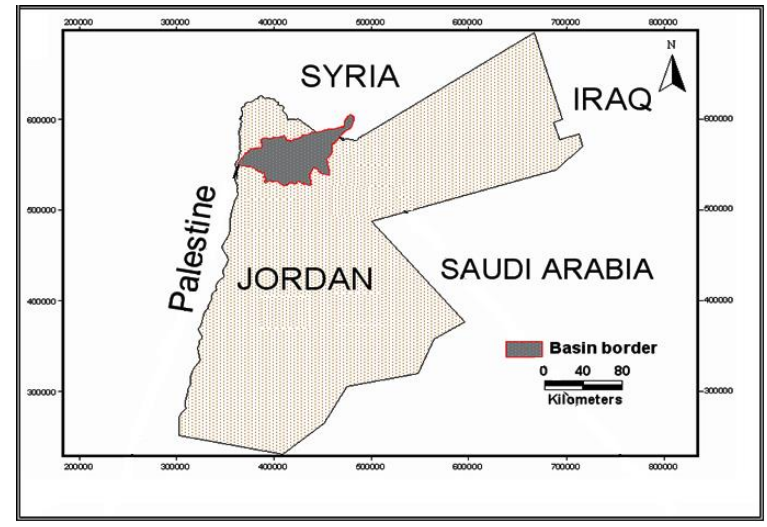

Figure 1. Map showing the location of the AZB.

high rainfall occurs. The basin is also covered by sporadic vegetation (normally used for grazing), bare soil, rocky areas and forests. In addition to the intensive agriculture with frequent use of fertilizers and pesticides, the basin has also suffered from unplanned industrial development which have resulted in land degradation and desertification, mining and salinization of groundwater, reduced river base flow, and deforestation processes. In addition, Zerqa River received wastewater discharged from Khirbet As-Samra wastewater treatment plant. Nitrate concentrations in excess of Jordan standards for drinking water are widespread, particularly in the intensively cultivated areas $[11,15,16]$. In Jordan, groundwater contamination is of particular concern as groundwater resources are the principal source of water for irrigation, drinking and industrial activities.

Protection of groundwater resources is always cheaper than remediation and restoration of the aquifer, and in most cases it is very difficult to remediate an aquifer to its original state. One of the tools supporting decisionmaking in aquifer protection is the evaluation of shallow aquifer vulnerability. Groundwater vulnerability maps have become a widely accepted tool in the land use planning process.

In this paper, The main objective is to produce vulnerability maps of groundwater resources in the AZB using the DRASTIC method, and develops a Modified DRASTIC model by combining the generic DRASTIC model with landuse activities and lineament density for the study area with a new model map that evaluates pollution potential of groundwater resources in AZB to various types of pollution. In addition, parameters to account for differences in land use and lineaments density were added to the DRASTIC model to reflect their influences on groundwater pollution potential Therefore, Two additional parameters were added to DRASTIC model in order to map the groundwater vulnerability in the study area more accurately: lineaments density and land use/land cover. The depth to water alone does not provide a protection for groundwater against the contaminants infiltration as it is possible that the pollutant may penetrate the aquifer through fractures even if the aquifer is deep [17]. Following this logic, the modified DRASTIC system is the sum of the original DRASTIC system and the fractures density which is obtained by using aerial photographs and geological maps. Also, the AZB contains many agricultural activities, industrial, and urban centers that depend on septic tanks that are the most hazardous potentials that may affect the groundwater. It is important to make clear the distinction between vulnerability and risk because risk of pollution is determined not only by the intrinsic characteristics of the aquifer (which are relatively static) but also by the existence of potentially polluting activities (which are dynamic factors that can in principle be both changed and controlled [18]. To evaluate potential risk, an additional parameter can be integrated into the analysis, which is the landuse map.

\section{Methodology}

\subsection{Materials and Data Sources}

All relevant data attributes were used to create the shape files with ESRI-GIS software, including the geological, hydrogeological, hydrological, hydrochemical, and environmental aspects in the study area, sources of data are presented in Table 1. Structural contour maps, drainage boundaries, groundwater flow systems, and the topographic map were digitized and converted into shape files (layers) (Table 1). Formation thickness, saturation thickness, and depth to water levels were also calculated. In addition, water samples were selected to cover most of the aquifers in the study area. Water samples in 54 wells (Figure 2) from different groundwater aquifers in the AZB were collected and sampled in one-liter polyethylene bottles and analyzed for $\mathrm{NO}_{3}^{-}$(by Spectrophotometer).

Water samples were stored in the refrigerator until analyzed to prevent deterioration and changes in water quality. The $\mathrm{pH}$ of each water sample was estimated by a $\mathrm{pH}$ meter. A spectrophotometer (Thermo, Evolution100) was used to determine the concentration of $\mathrm{NO}_{3}^{-}$. Nitrate concentration was determined by adding $25 \mathrm{~mL}$ from each sample into an Erlenmeyer flask. $0.5 \mathrm{~mL} 1 \mathrm{~N} \mathrm{HCl}$ was added to the sample and to the blank (distilled water) and the absorbance was measured by the use of a spectrophotometer at $220 \mathrm{~nm}$ [19]. A calibration curve 


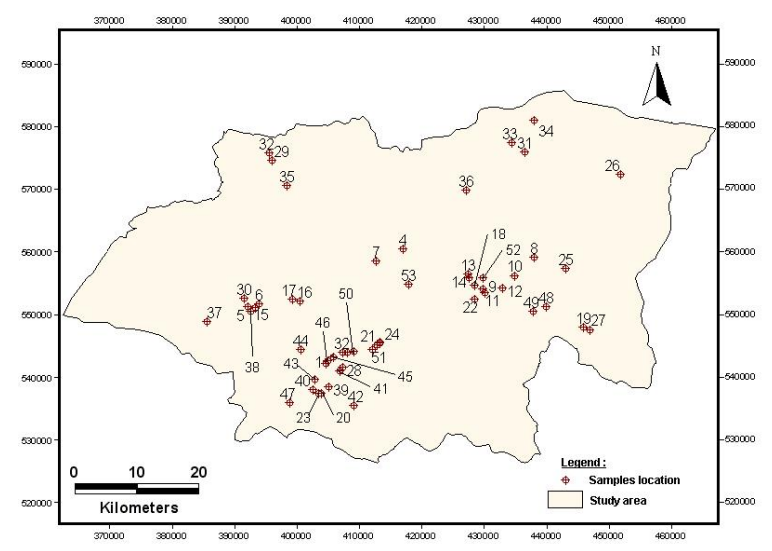

Figure 2. Locations of water samples in the study area.

was used to determine the expected ion concentration of a measured sample. The curve contained at least three concentrations of each standard ion solution. When plotting the absorbance of the desired standard with its concentration, the curve must have a linear relationship with regressions (R2) and cover more than $99 \%$ of the calibrated range; taking into consideration that all of the reference standards were certified.

\subsection{Groundwater Aquifers}

The hydrogeology of the study area is controlled by the dominant geological structures that affect water level, movement, and occurrence of groundwater. The principal factors in determining the potential of the area to be water-bearing is the permeability and secondary porosity, both of which are directly related to the structure [23]. Groundwater occurs mostly in fractured and cavernous limestone, fractured chert; sandstone voids, and wadi fill deposits, which includes four aquifer systems. The Aquifer Complex for the AZB is split up into three sections. The upper aquifer complex consists of limestone and marl of the Upper Cretaceous with a thickness ranging between of 600 and $700 \mathrm{~m}$. Groundwater generally moves eastwards and is made up of the alluvial deposits aquifer, restricted to major wadis and plateau gravel deposits (silts, clays, and gravel); basalt aquifer. It covers most of Wadi Dhuleil and north-east desert areas, and Amman-Wadi Sir (B2/A7) aquifer, overlying the Hummer Aquifer (comprised of $\mathrm{Al}$ Hisa, B2, and Wadi Es Sir, A7), which composed of chert and limestone.

The middle aquifer system (the late Cretaceous aquifers) consists of Hummar (A4) and Na'ur (A1/2) formations. The

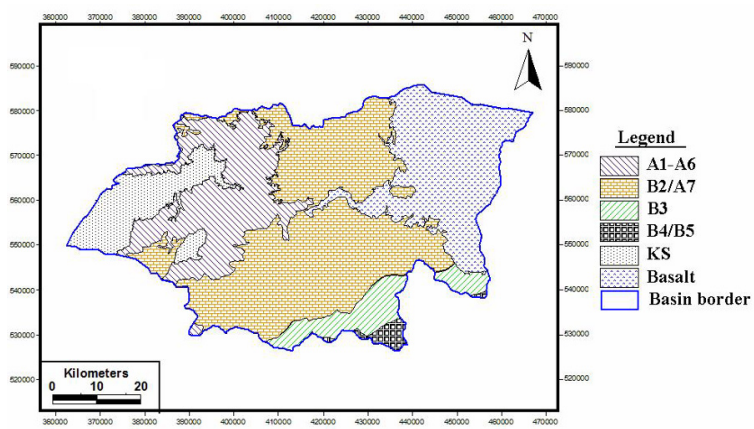

Figure 3. Hydrogeological map of the study area (modified after [20]).

Upper Cretaceous aquifers, within the Ajlun and Belqa groups, represent the main aquifers in the study area. The Ajlun group yields water generally from limestone and dolomitic limestone, whereas the Belqa group drains its water from the limestone and chert horizons. The A1/2 is a confined aquifer, separated from A4 by a thick bed of Fuheis marl aquifer (A3). Two subunits are recognized within this aquifer: the lower part (A1) consists of marls and ranges in thickness between 60 and $120 \mathrm{~m}$, forming the confining layer that separates the A1/2 from the underlying Kurnub Sandstone Aquifer. The upper part (A2) consists of a thick limestone layer of 100 and $150 \mathrm{~m}$ thickness (Figure 3) [23]. The lower aquifer complex, with a thickness increasing northward, consists of sandstone interrupted by thin layers of marl and limestone from the lower Cretaceous. According to Salameh and Udulft [24], the thickness is about $600 \mathrm{~m}$ with a general groundwater movement towards the west. The lower aquifer system consists of the Kurnub group with a maximum thickness of about $300 \mathrm{~m}$ [25]. It crops out in the north of the upper AZB and encounters at a depth of about $480 \mathrm{~m}$ south of Amman and $530 \mathrm{~m}$ near Zerqa. It is a semi-confined aquifer that underlies the carbonate aquifers and is separated by the marls and shales of Na'ur formation by a thickness of about $100 \mathrm{~m}$. More details of the geology is shown in Figure 4.

\subsection{Generic DRASTIC Model}

DRASTIC method to estimate vulnerability of an aquifer is a popular tool because of the minimum data requirement. The concept of groundwater vulnerability is based on the assumption that the physical environment may provide some degree of protection to groundwater against natural impacts, especially with regard to contaminants entering the subsurface environment [27]. Vulnerability maps show 
Table 1. Data sources for the DRASTIC model.

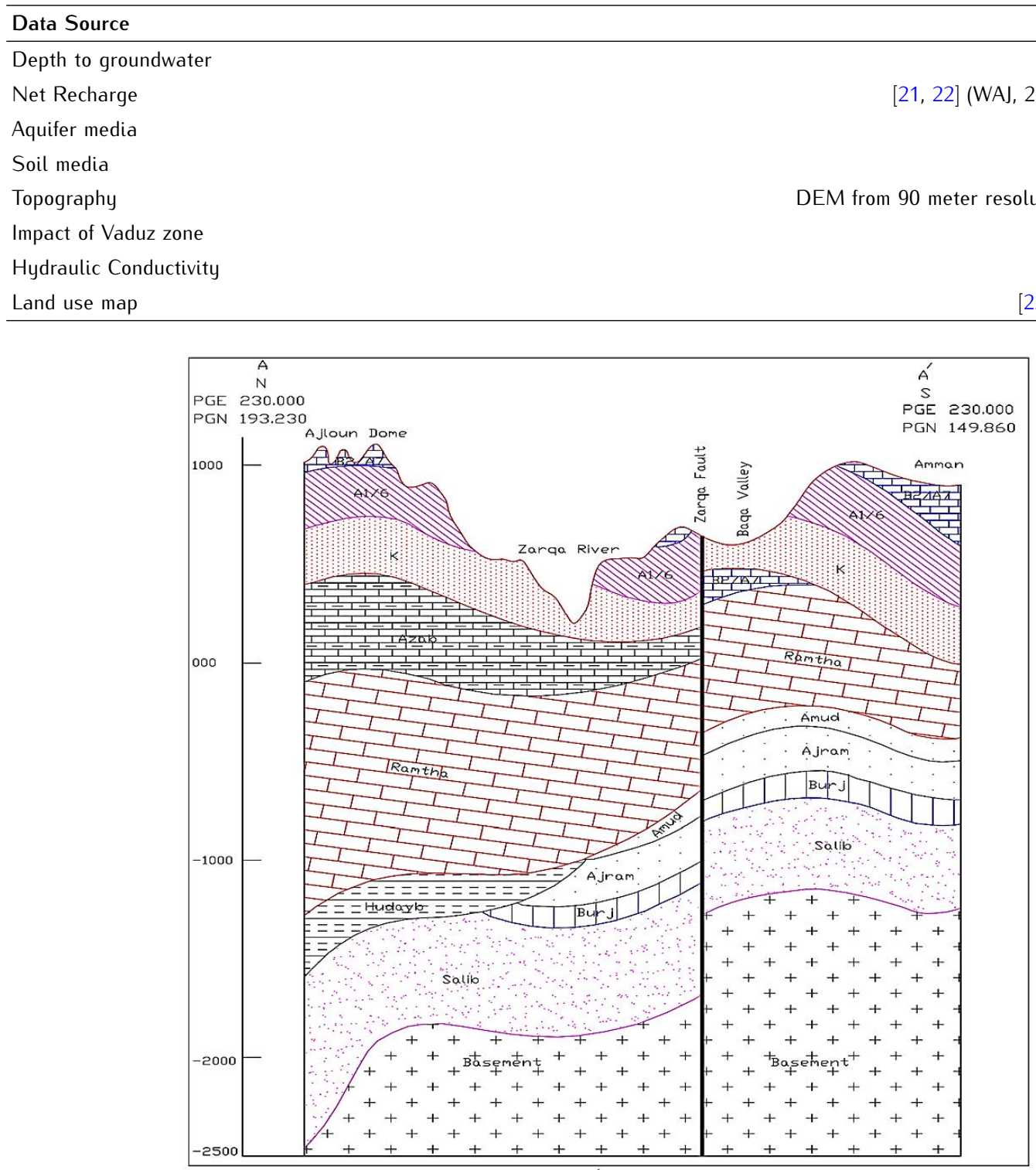

Figure 4. Geological cross-section A-A' from Amman Zerqa Basin [26].

the distribution of areas that are highly vulnerable to contamination.

The DRASTIC model uses seven parameters of the natural system, which are rated from 1 to 10 . Each parameter is then weighted from 1 to 5 . The rates and weights are multiplied for each parameter and added together to produce a so-called vulnerability index $[8,28-31]$. The most significant parameters have weights of 5 , and
Criteria

[20] (WAJ, 2006)

; (MOA, 1994)

[20] (WAJ, 2006)

[21] (MOA, 1994)

(Radar DEM)

[20] (WAJ, 2006)

[20] (WAJ, 2006)

[22] (Salameh, 2006) 
also assigned a subjective rating. Weight multipliers are then used for each factor to balance and enhance their importance. The final vulnerability map is based on the DRASTIC index $(D I)$ which is computed as the weighted sum overlay of the seven layers, using Equation (1):

$$
\begin{aligned}
D I= & D r \cdot D w+R r \cdot R w+A r \cdot A r+S r \cdot S w+T r \cdot T w \\
& +I r \cdot I w+C r \cdot C w
\end{aligned}
$$

where $D, R, A, S, T, I$, and $C$ are the seven parameters; $r$ is the rating value, and $w$ is the weight associated with each parameter (Table 4).

Once the DRASTIC Index is computed, it is possible to identify areas that are more susceptible to groundwater contamination. The higher the DRASTIC Index, the greater the groundwater pollution potential. The seven sets of data layers are digitized and converted to raster data sets that are processed using ArcGIS 9.2. In the DRASTIC method, it is assumed that: (1) the contaminant is introduced at the ground surface; (2) the contaminant is flushed into the groundwater by precipitation; (3) the contaminant has the mobility of water; and (4) the area evaluated is 100 acres or larger [28]. Furthermore, the numerical weights and ratings, established using the Delphi technique [20], are well defined and have been used worldwide $(2,8,27,32,33,34,35,36,37,38)$. The Delphi technique uses the practical and research experiences of professionals in the area of interest to assess levels of risk. The sources for the seven factors are presented in (Table 1).

\subsection{Modifications of DRASTIC Model}

\subsubsection{Modified DRASTIC Model based on Lineaments Density Map}

The lineaments refer to as linear features detected on aerial photographs and satellite images, which presumably have a geological origin. Generally, lineaments are underlain by a zone of localized weathering and increased permeability and porosity. Previous studies have revealed a close relationship of lineaments (or lineaments density) and groundwater flow and yield [39-44]. Therefore, mapping of lineaments is essential to groundwater surveys, development and management [45]. Higher lineament density values may indicate more potential groundwater contamination. A lineaments map is derived from Enhanced Thematic Mapper plus (ETM+) satellite imagery.

In the study area, most of the aquifers are developed in fractured rock, so groundwater mainly moves through fault and fracture. Integrated lineament density and the DRASTIC model assess groundwater susceptibility more accurately. The method of photolineament factor value calculation is shown in (Figure 6).

The calculated lineament density was assigned ranges and ratings according to Table 4 . The weight of lineament density was assigned a value based on its relative importance. Figure 7 shows the lineament density as assigned by ranges and ratings (Table 4) and overlaid with the DRASTIC model. The modified DRASTIC system index was calculated using Equation (2):

$$
D L(i)=D I+(\text { Lineament Density Index })
$$

where: $D L(i)$ is the modified DRASTIC model using lineament density; $D I$ is the generic DRASTIC index and the (lineament density index (ratings. weights)).

Table 4 shows the distribution of the lineament density rate of the study area; the value of 1 covers $77.08 \%$, the value of 5 covers $3.20 \%$, and the value of 10 covers $0.432 \%$ of the study area.

\subsubsection{Modified DRASTIC Model based on Land Use Map}

It is important to make a clear distinction between vulnerability and risk. This is due to the fact that risk of pollution is determined not only by the intrinsic characteristics of the aquifer (which are relatively static) but also by the existence of potentially polluting activities (which are dynamic factors) that can in principle be both changed and controlled [18]. To evaluate potential risk, an additional parameter can be integrated into the analysis, which is the land use map. Land use map is an important factor that must be included in groundwater vulnerability maps because it strongly affects the groundwater quality as shown in Table 5.

The extensive land use, mainly agriculture, can result in potential changes of soil nature and hydraulic conductivity [46]. Thus, land use is rated and weighted as additional DRASTIC model factor. ETM + satellite imagery was used to infer categories of land use/land cover in the study area in order to introduce a land use factor into DRASTIC index. The land use map of the AZB is shown in Figure 8.

The western and northeastern parts of the study area contain more than $31.79 \%$ of agricultural activities and vegetation. According to the National Soil Map and Land use Project of Jordan, the land use of the AZB varies from urban and non-agricultural land, to non-vegetated and sparsely vegetated land (bare rocks and basalt) to ruined agricultural land (open field crops and fallow lands). Remote sensing technique was used to produce the land use map using satellite Landsat images (ETM+, 2002). Accordingly, the total amount of irrigated land 
Table 2. DRASTIC parameters used in the study [28].

\begin{tabular}{|c|c|c|c|c|}
\hline \multicolumn{5}{|l|}{ 1. Depth to Groundwater } \\
\hline Ranges (m) & Ratings(Dr) & Index (D) & Area $(\%)$ & Area $\left(\mathrm{km}^{2}\right)$ \\
\hline $0-1.5$ & 10 & 50 & 0.03 & 1 \\
\hline $1.5-4.75$ & 9 & 45 & 0.08 & 3 \\
\hline $4.75-9.14$ & 7 & 35 & 0.18 & 17 \\
\hline $9.14-15.24$ & 5 & 25 & 0.5 & 19 \\
\hline $15.24-22.86$ & 3 & 15 & 1.08 & 41 \\
\hline $22.86-30.48$ & 2 & 10 & 5.12 & 194 \\
\hline$>30.48$ & 1 & 5 & 93.01 & 3527 \\
\hline \multicolumn{5}{|l|}{ Weight 5} \\
\hline \multicolumn{5}{|l|}{ 2. Net Recharge (mm/year) } \\
\hline $3-5$ & 1 & 2 & 18.58 & 663 \\
\hline $5-7$ & 3 & 6 & 45.01 & 1606 \\
\hline 7-9 & 5 & 10 & 36.41 & 1299 \\
\hline \multicolumn{5}{|l|}{ Weight 2} \\
\hline \multicolumn{5}{|l|}{ 3. Aquifer Media } \\
\hline Muwaqqar chalky marl (marl, limestone) & 2 & 6 & 6.2 & 233.75 \\
\hline Kurnub (Sandstone) & 6 & 18 & 9.4 & 357.85 \\
\hline Lower Ajlun (marl, limestone, dolomite) & 8 & 24 & 20.1 & 762.96 \\
\hline \multicolumn{5}{|l|}{ Rijam/Wadi Shallaleh (limestone, chalk, chert) } \\
\hline Basalt & 9 & 27 & 64.3 & 2438.46 \\
\hline \multicolumn{5}{|l|}{ Amman/Wadi Sirlimestone (dolomitic limestone) } \\
\hline \multicolumn{5}{|l|}{ Weight 3} \\
\hline \multicolumn{5}{|l|}{ 4. Soil Media } \\
\hline Clay Loam & 3 & 6 & 17.16 & 651 \\
\hline Silty Loam & 4 & 8 & 39.86 & 1512 \\
\hline Loam & 5 & 10 & 15.21 & 577 \\
\hline Shrinking and/or & 7 & 14 & 19.22 & 729 \\
\hline Sand & 8 & 16 & 8.54 & 324 \\
\hline \multicolumn{5}{|l|}{ Weight 2} \\
\hline \multicolumn{5}{|l|}{ 5. Topography (\%) } \\
\hline $0-2$ & 1 & 1 & 12.5 & 447 \\
\hline $2-6$ & 3 & 3 & 13.22 & 473 \\
\hline $6-12$ & 5 & 5 & 14.23 & 509 \\
\hline $12-18$ & 9 & 9 & 30.22 & 1081 \\
\hline$>18$ & 10 & 10 & 29.83 & 1067 \\
\hline \multicolumn{5}{|l|}{ Weight 1} \\
\hline \multicolumn{5}{|l|}{ 6. Impact of the Vadose Zone } \\
\hline Silt/clay & 2 & 10 & 1.53 & 58 \\
\hline Shale, Limestone & 3 & 15 & 40.68 & 1543 \\
\hline Sandstone, Bedded limestone, Sand and gravel with silt & 6 & 30 & 35.51 & 1347 \\
\hline Sand and gravel & 8 & 40 & 19.88 & 754 \\
\hline Basalt & 9 & 45 & 2.4 & 91 \\
\hline \multicolumn{5}{|l|}{ Weigh 5} \\
\hline \multicolumn{5}{|l|}{ 7. Hydraulic Conductivity $(\mathrm{m} / \mathrm{s})$} \\
\hline $4.716 \cdot 10^{-7}-4.716 \cdot 10^{-5}$ & 1 & 3 & 18.96 & 719 \\
\hline $4.716 \cdot 10^{-5}-1.41 \cdot 10^{-4}$ & 2 & 6 & 38.1 & 1445 \\
\hline $1.41 \cdot 10^{-4}-3.3 \cdot 10^{-4}$ & 4 & 12 & 15.37 & 583 \\
\hline $3.3 \cdot 10^{-4}-4.716 \cdot 10^{-4}$ & 6 & 18 & 8.28 & 314 \\
\hline $4.716 \cdot 10^{-4}-9.43 \cdot 10^{-4}$ & 8 & 24 & 17 & 647 \\
\hline$>9.43 \cdot 10^{-4}$ & 9 & 27 & 2.24 & 85 \\
\hline Weigh 3 & & & & \\
\hline
\end{tabular}


(a)
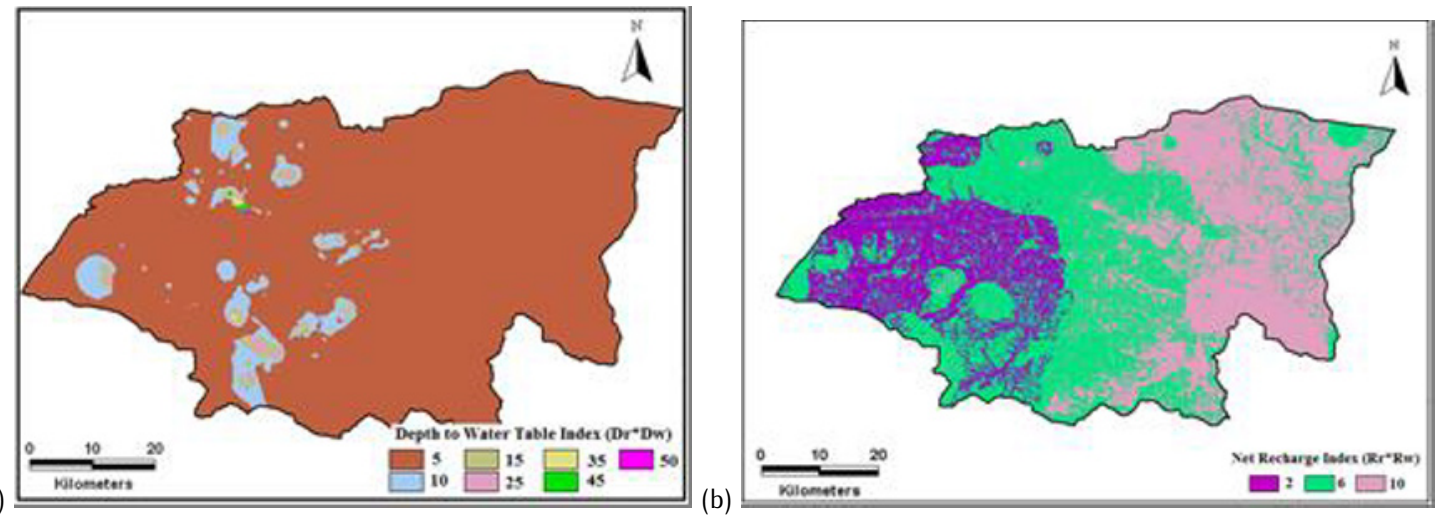

(c)
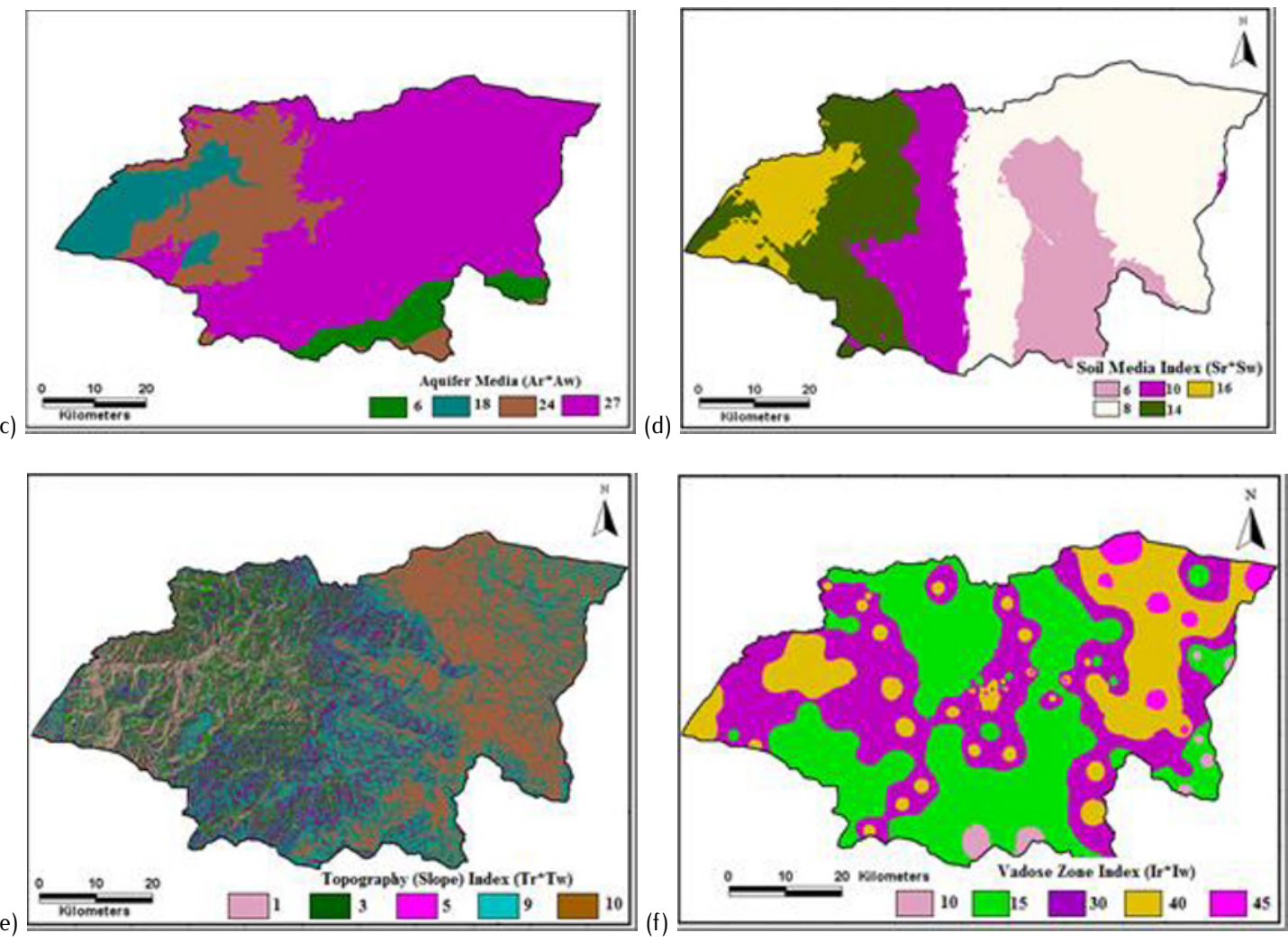

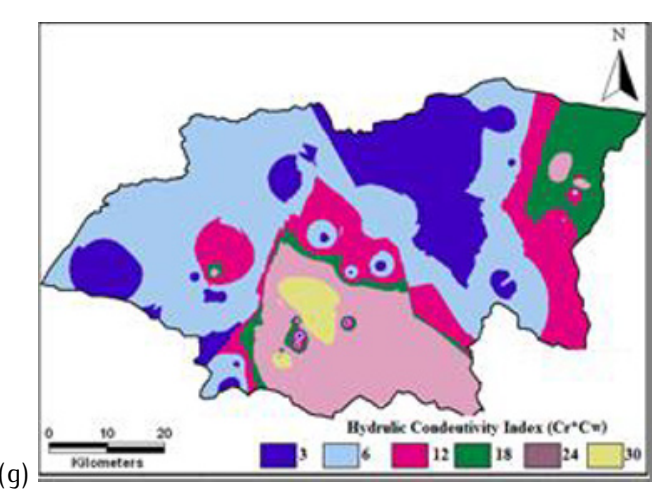

Figure 5. (a) Map index of depth-to groundwater table, (b) The spatial distribution for the ratings of the net recharge parameter, (c) Surface distribution of the hydrological units, (d) the spatial distribution for the index of the soil media parameter, (e) the spatial distribution for the ratings of the slope parameter, (f) the spatial distribution for the ratings of the unsaturated zone parameter, (g) Map index of hydraulic conductivity. 
Table 3. Description and original weights of the intrinsic and specific model parameters [32].

\begin{tabular}{|c|c|c|}
\hline The DRASTIC model parameters & Parameters description & Original weight \\
\hline Depth to water & $\begin{array}{l}\text { Represents the depth from the groundwater table levels, the deeper the } \\
\text { groundwater table, the lesser chance for contamination to occur }\end{array}$ & 5 \\
\hline Net Recharge & $\begin{array}{l}\text { Represents the amount of water which penetrates the ground surface and reaches } \\
\text { the water table, recharge water represents the vehicle for transporting pollutants }\end{array}$ & 4 \\
\hline Aquifer media & $\begin{array}{l}\text { Refers to the saturated zone material properties, which controls the pollutant } \\
\text { attenuation processes. }\end{array}$ & 3 \\
\hline Soil media & $\begin{array}{l}\text { Represents the uppermost weathered portion of the unsaturated zone and } \\
\text { controls the amount of recharge that can infiltrate downward }\end{array}$ & 2 \\
\hline Topography & $\begin{array}{l}\text { Refers to the slope of the land surface, it dictates whether the runoff will remain } \\
\text { on the surface to allow contaminant percolation to the saturated zone. }\end{array}$ & 1 \\
\hline Impact of vadose zone & $\begin{array}{l}\text { Is the unsaturated zone material, it controls the passage and attenuation of the } \\
\text { contaminated material to the saturated zone. }\end{array}$ & 5 \\
\hline Hydraulic Conductivity & $\begin{array}{l}\text { Indicates the ability of the aquifer to transmit water, hence determines the rate } \\
\text { of flow of contaminant material within the groundwater system. }\end{array}$ & 3 \\
\hline
\end{tabular}

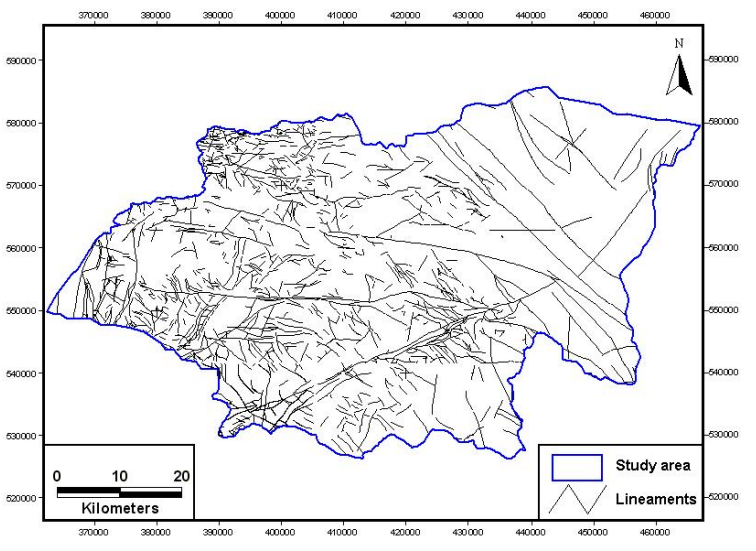

Figure 6. Lineament map of the AZB.

Table 4. Ranges and ratings of lineament density.

\begin{tabular}{lrrr}
\hline $\begin{array}{l}\text { Range of the } \\
\text { Distribution of } \\
\text { Density }\end{array}$ & Rating & Area $\left(\mathbf{k m}^{2}\right)$ & Area (\%) \\
\hline $0.2-1.1$ & 1 & 2913 & 77.08 \\
$1.2-1.3$ & 2 & 297 & 7.86 \\
$1.4-1.5$ & 3 & 231 & 6.11 \\
$1.5-1.8$ & 4 & 144 & 3.81 \\
$1.9-2.0$ & 5 & 121 & 3.2 \\
$2.1-2.2$ & 6 & 28 & 0.741 \\
$2.3-2.4$ & 7 & 14 & 0.37 \\
$2.5-2.6$ & 8 & 10 & 0.265 \\
$2.7-2.8$ & 9 & 5 & 0.132 \\
$2.9-4.0$ & 10 & 16 & 0.432 \\
\hline
\end{tabular}

(a)

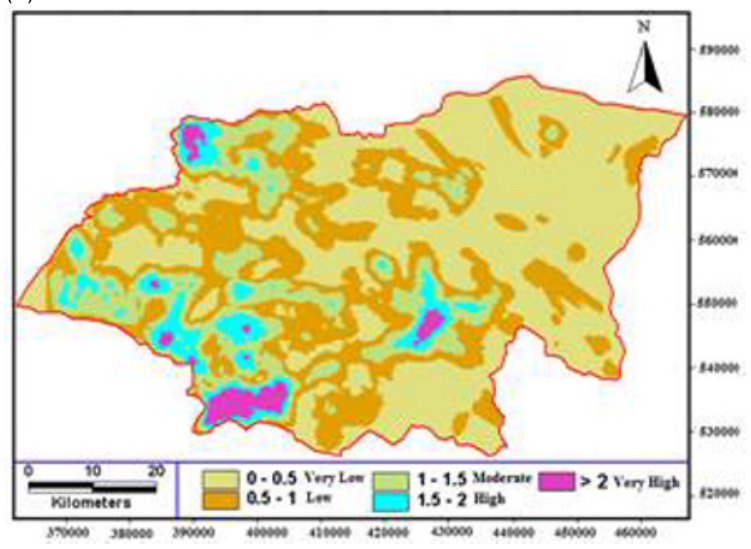

(b)

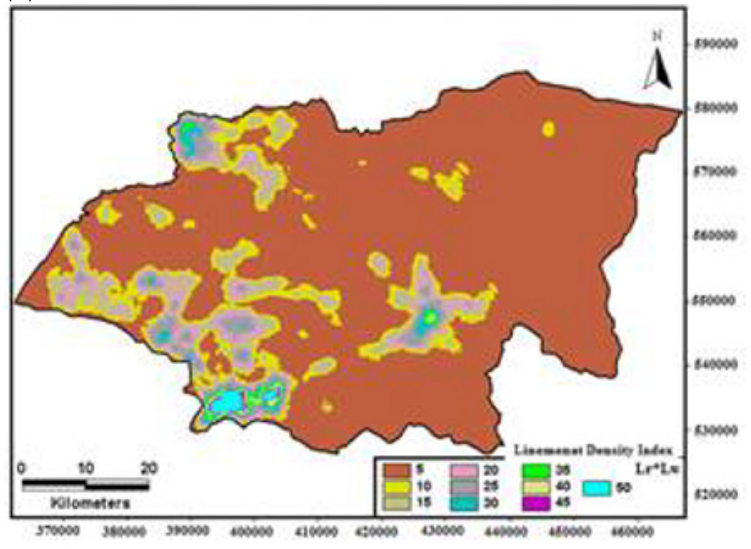

Figure 7. (a) Lineament density map of AZB; (b) Map of lineament density index. 


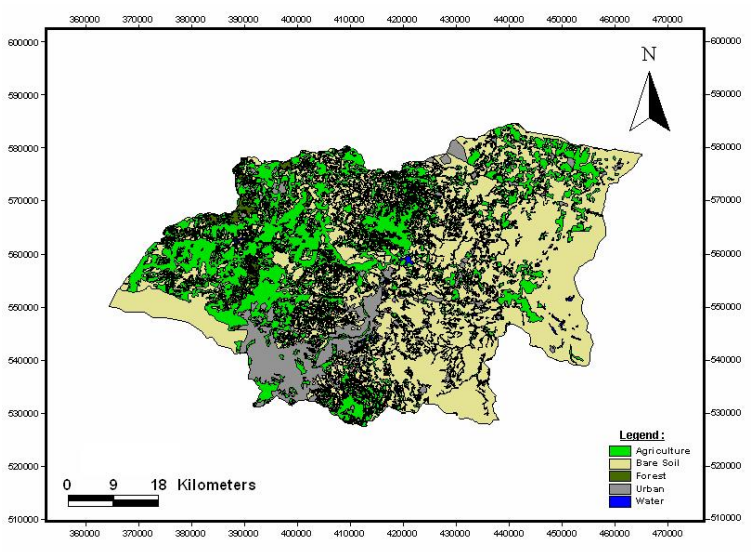

Figure 8. The major land use classes in the AZB (modified after [22]).

Table 5. Land use categories for the study area and the weights of the parameters [47].

\begin{tabular}{llll}
\hline Land use category & Rate & Area $\left(\mathbf{k m}^{2}\right)$ & Area (\%) \\
\hline Urban & 3 & 366 & 9.75 \\
Irrigated agriculture & 2 & 1193 & 31.79 \\
Uncultivated land & 1 & 2102 & 56.09 \\
Forest & 1 & 76 & 2.03 \\
Land use weight $(L w)$ & 5 & & \\
\hline
\end{tabular}

(Highlands, Wadi Dhuleil, and Khaldiya areas) is about $17,000,000 \mathrm{~m}^{2}$ [22]. Based on Figure 8, the land use types of the AZB are: $56.09 \%$ bare rock, $41.54 \%$ thin soils and urbanization, whereas the remaining area is water and forest (Table 5).

The land use map (Figure 8) was rated according to the values given in Table 5. The map was converted to a raster grid and multiplied by the weight of the parameters $(L w=5)$ as shown in Figure 9. The resulting grid coverage was then added to the DRASTIC index, based on Equation (3) [47].

$$
M D(i)=D I+(\text { Land Use Index })
$$

where: $M D(i)$ is the modified DRASTIC risk assessment model; $D I$ is the generic DRASTIC index and the land use index (ratings.weights).

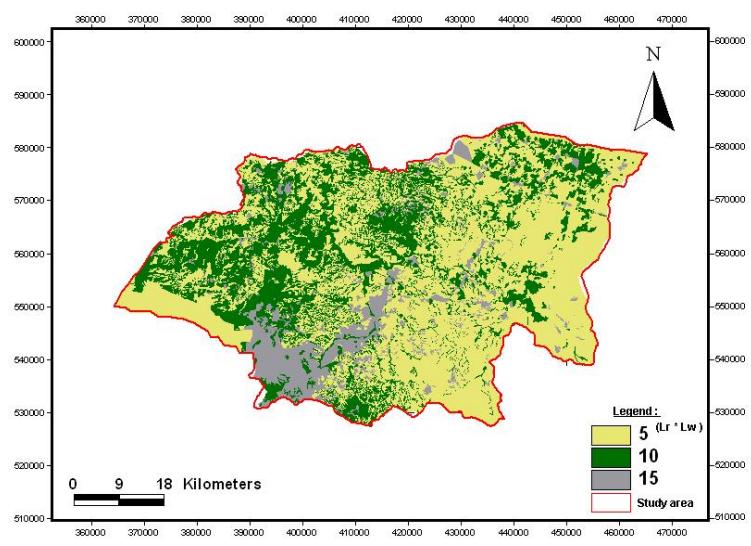

Figure 9. The result of multiplying the land use $(L r \cdot L w)$.

Table 6. DRASTIC index categories and areas vulnerable to groundwater pollution in the AZB.

\begin{tabular}{llll}
\hline $\begin{array}{l}\text { Vulnerability } \\
\text { Class }\end{array}$ & $\begin{array}{l}\text { DRASTIC } \\
\text { Index }\end{array}$ & Area $\left.\mathbf{( k m}^{2}\right)$ & Area $(\%)$ \\
\hline No & $24-61$ & 45 & 1.19 \\
Low & $62-99$ & 2624 & 69.20 \\
Moderate & $100-137$ & 1120 & 29.54 \\
High & $138-175$ & 3 & 0.08 \\
Total & & $3792 \mathrm{~km}^{2}$ & $100 \%$ \\
\hline
\end{tabular}

\section{Results and Discussion}

\subsection{Assessment of Aquifer Vulnerability Based on the Generic DRASTIC Model}

The DRASTIC model used to produce a vulnerability map of the study area was computed by the sum of each parameter rating multiplied by the assigned weights using ArcGIS, as shown in Equation (1). The higher the calculated DRASTIC index, the greater the potential for groundwater contamination is. The final DRASTIC vulnerability map (Figure 10) was generated by overlaying all seven layers, resulting in a DRASTIC index range of 24-175, which was reclassified according to the criteria in Table 6 and Figure 10. Table 6 shows the DRASTIC index and vulnerability class.

The results indicate that only $0.08 \%\left(3 \mathrm{~km}^{2}\right)$ of the AZB is within the high vulnerability zone with a DRASTIC index values ranging from 138 to 175 , and is mainly in the central area of Amman old city. It could be noticed that the wells with relatively higher $\mathrm{NO}_{3}^{-}$concentrations are those in the Industrial activities and high density 


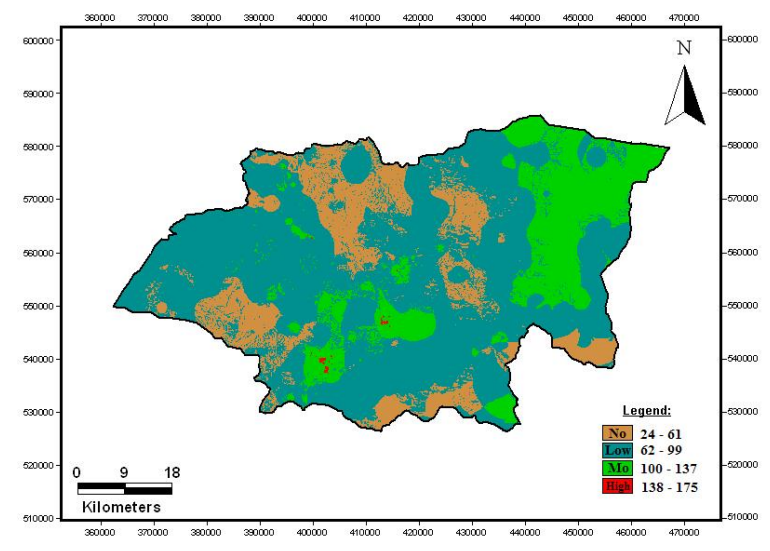

Figure 10. Generic DRASTIC vulnerability map classes of groundwater.

urban areas centers that depend on septic tanks which are the most hazardous potentials that might affect groundwater. Approximately $30 \%$ of the basin is located in the moderately vulnerable zone. Interestingly, the proposed location of the nuclear power plant (in central basin) is within the moderate vulnerability zone.

\subsection{Assessment of Aquifer Vulnerability Based on Lineaments Density}

The minimum possible modified DRASTIC index, using the lineaments density parameter, is 29 and the maximum is 225 (Figure 11). This range of values was divided into four classes as follows: (a) 29-75 (No risk), (b) 76-122 (Low), (c) 123-169 (Moderate), (d) 170-225 (High).

The vulnerability map shows that approximately $87.03 \%$ of the area is classified as having low pollution potential with values ranging between 76 and 122 . The no vulnerability class for the modified DRASTIC lineament density index has values varying from 29 to 75 , which is about $5.01 \%$ of the AZB area. The moderately susceptible zone accounts for $7.83 \%$ of the basin's total area with values that vary from 123 to 169 . The high vulnerability class has values ranging between 170 and 225, which constitutes $0.13 \%$ of the basin's area (Table 7 and Figure 11).

\subsection{Assessment of Aquifer Vulnerability Based on Land use}

The range of the Modified DRASTIC risk assessment index MD (i) based on land use is 29-255. The range of values was divided into four classes: (a) 29-68 (No risk), (b)

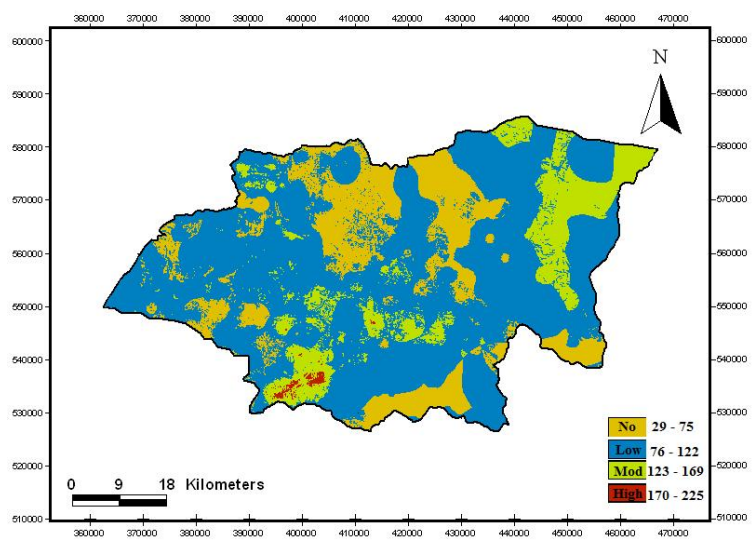

Figure 11. Generic DRASTIC vulnerability map classes of groundwater.

Table 7. Modified DRASTIC index categories using lineament density and areas vulnerable to groundwater pollution.

\begin{tabular}{llll}
\hline $\begin{array}{l}\text { Vulnerability } \\
\text { Class }\end{array}$ & $\begin{array}{l}\text { DRASTIC } \\
\text { Index }\end{array}$ & Area $\left.\mathbf{( k m}^{2}\right)$ & Area (\%) \\
\hline No & $29-75$ & 190 & 5.01 \\
Low & $76-122$ & 3300 & 87.02 \\
Moderate & $123-169$ & 297 & 7.83 \\
High & $170-225$ & 5 & 0.13 \\
Total & & $3792 \mathrm{~km}^{2}$ & $100 \%$ \\
\hline
\end{tabular}

69-108 (Low), (c) 109-148 (Moderate), and (d) 149-190 (High) (Table 8 and Figure 12).

The vulnerability map shows that about $71 \%$ of the study area has low pollution potential with values ranging between 69 and 108. No vulnerability area accounts for about $0.55 \%$ whereas moderate pollution potential zone covers an area of $28.35 \%$. The high vulnerability class based on the DRASTIC Modified risk assessment index with values ranging between 149 and 190, constitutes

Table 8. Modified risk assessment index MD (i) (using land use) for the study area.

\begin{tabular}{llll}
\hline $\begin{array}{l}\text { Vulnerability } \\
\text { Class }\end{array}$ & $\begin{array}{l}\text { DRASTIC } \\
\text { Index }\end{array}$ & Area $\left(\mathbf{k m}^{2}\right)$ & Area (\%) \\
\hline No & $29-68$ & 21 & 0.55 \\
Low & $69-108$ & 2692 & 70.99 \\
Moderate & $109-148$ & 1075 & 28.35 \\
High & $149-190$ & 4 & 0.11 \\
Total & & $3792 \mathrm{~km}^{2}$ & $100 \%$ \\
\hline
\end{tabular}




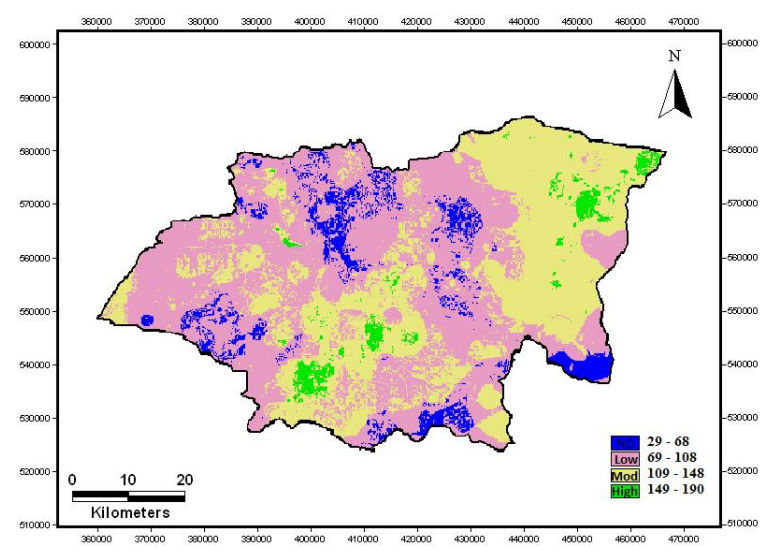

Figure 12. Final Modified DRASTIC risk assessment class's index

$0.11 \%$ of AZB (Table 8 and Figure 12).

Urban areas were assigned a probability rating of 3 (Table 5), because nitrogen species concentrations in groundwater in urban areas were higher than in all other land use areas, whereas irrigated agriculture areas were assigned a probability rating of 2 . Rangeland, dryland agriculture, and forest areas were combined and assigned a probability rating of 1 , as they contain low nitrogen of nearly similar concentrations.

\subsection{Assessment of Aquifer Vulnerability Based on the Modified DRASTIC Model}

The modified DRASTIC system index was calculated using Equation (4):

$$
\text { Final Modified DRASTIC }=D I+D L(i)+M D(i)
$$

DI: DRASTIC Vulnerability Map; $D L(i)$ : DRASTIC Modified Lineament density index; $M D(i)$ : DRASTIC Modified risk assessment index. The final DRASTIC $(D I+D L(i)+M D(i))$ values were classified into No, Low, Moderate, and High pollution potential classes. The vulnerability map shows that slightly more than $89 \%$ of the area falls under low pollution potential with final DRASTIC values ranging between 83 and 131. The no vulnerability final DRASTIC index values ranging between 34 and 82, accounts for about 5.9\%. The moderate pollution potential covers an area about $4.24 \%$ of AZB. The high vulnerability class of values 181-229, accounts for about $0.21 \%$ of the basin (Table 9 and Figure 13).
Table 9. The final modified DRASTIC index $(D I+D L(i)+M D(i))$ for the study area.

\begin{tabular}{llll}
\hline $\begin{array}{l}\text { Vulnerability } \\
\text { Class }\end{array}$ & $\begin{array}{l}\text { DRASTIC } \\
\text { Index }\end{array}$ & Area $\left.\mathbf{( k m}^{2}\right)$ & Area (\%) \\
\hline No & $34-82$ & 223 & 5.88 \\
Low & $83-131$ & 3400 & 89.66 \\
Moderate & $132-180$ & 161 & 4.24 \\
High & $181-229$ & 8 & 0.21 \\
Total & & 3792 & 100 \\
\hline
\end{tabular}

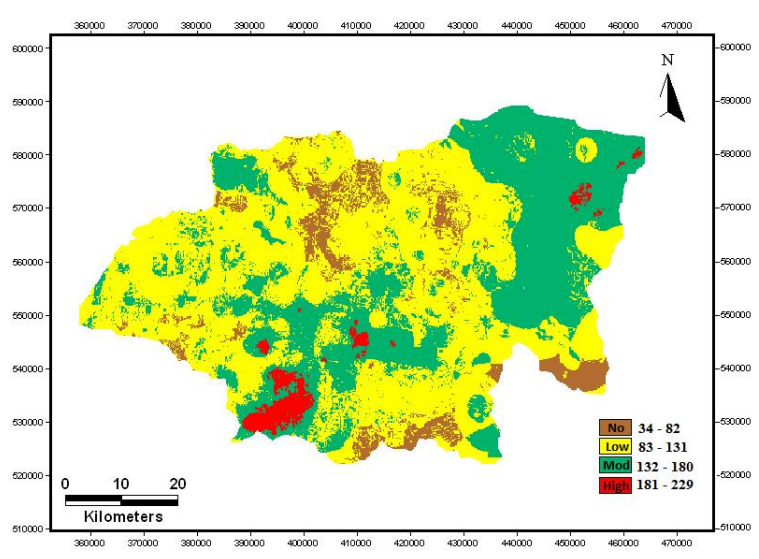

Figure 13. The final modified DRASTIC vulnerability index map of groundwater in AZB.

\subsection{The Vulnerability of Groundwater Pollution and Land Use}

The relationship between groundwater and land use in the study area was assessed. Data were cross-tabulated for the sensitivity of groundwater pollution in terms of description (No, Low, Moderate, and High) and the landuse map (Agriculture, Urban, Bare soil and Forest). The final relationship is shown in Table 10 and Figure 14.

Table 10 and Figure 14 show that a total area of about $1761 \mathrm{~km}^{2}$ of bare soils is of low vulnerability, whereas about $28 \mathrm{~km}^{2}$ is moderately vulnerable. While these areas are largely unexploited, the moderate vulnerability class must be used with caution. The area must be carefully managed to prevent further deterioration (above moderate vulnerability) in the future.

For agriculture and the urban sector approximately $1472 \mathrm{~km}^{2}$ are located within the low vulnerability zone and about $144 \mathrm{~km}^{2}$ are moderately vulnerable, which together account for about $8 \%$ of the total agriculture and urban area (Table 10). Thus, these areas are contaminated with human activities, particularly from the 
Table 10. Distribution of land use within the sensitive groundwater vulnerability.

\begin{tabular}{llllll}
\hline Vulnerability Class & Agriculture & Urban & Bare Soil & Forest & Total $\left(\mathbf{k m}^{2}\right)$ \\
\hline No & 44.704 & 2.333 & 184.575 & 5.605 & 237.322 \\
Low & 1200.007 & 271.577 & 1761.248 & 69.749 & 3315.200 \\
Moderate & 52.674 & 91.465 & 28.067 & 0.559 & 173.348 \\
High & 0.008 & 0.089 & 0.000 & 0.000 & 0.097 \\
Total $\left(\mathrm{km}^{2}\right)$ & 1297.385 & 365.464 & 1973.897 & 75.913 & 3690 \\
\hline
\end{tabular}

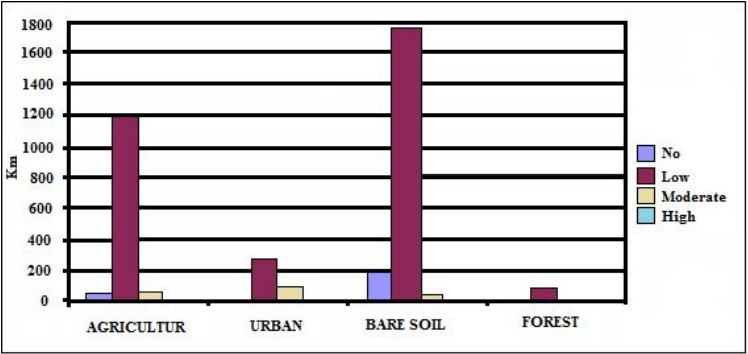

Figure 14. Histogram showing distribution of land use with sensitive groundwater vulnerability.

agriculture. Management of land use must be considered when changing human or agricultural activity patterns in the study area, to reduce groundwater vulnerability in the basin.

\subsection{Groundwater Vulnerability and Nitrate Concentration}

Nitrate $\left(\mathrm{NO}_{3}^{-}\right)$is among the most important indicators of water resource contamination. It comes into the water supply through the nitrogen cycle, rather than from dissolved minerals [47]. Although point sources of nitrogen, such as septic systems, contribute to the nitrate pollution of groundwater [48], most of the nitrate in groundwater is from fertilizers applied to agricultural fields [50-52]. Urban development can also increase the nitrate concentration in groundwater $[53,54]$ through landfills, septic tanks and cesspools, domestic and industrial effluents, and leaky sewage systems and gasoline stations [54-56]. Distribution of $\mathrm{NO}_{3}^{-}$ concentrations are presented in Figure 15.

It was observed that samples with high $\mathrm{NO}_{3}^{-}$ concentrations were found in the high vulnerability zone (Figure 16). $\mathrm{NO}_{3}^{-}$concentration in groundwater in the southwestern part of the study area, around the central Amman city, is ranging between 81 to $107 \mathrm{mg} / \mathrm{l}$ with an average concentration of about $98 \mathrm{mg} / \mathrm{l}$. The

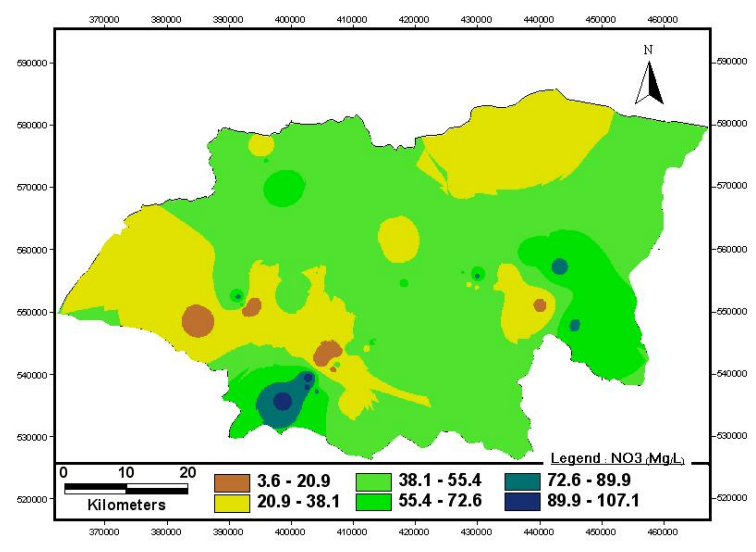

Figure 15. $\mathrm{NO}_{3}^{-}$concentrations in groundwater samples from the study area.

maximum acceptable $\mathrm{NO}_{3}^{-}$level in drinking water is $50 \mathrm{mg} / \mathrm{l}$ based on Jordan drinking water standards (or $45 \mathrm{mg} / \mathrm{l}$ according to the WHO). Generally, $\mathrm{NO}_{3}^{-}$ concentration above $10 \mathrm{mg} / \mathrm{l}$ in groundwater indicates anthropogenic contamination. $\mathrm{NO}_{3}^{-}$concentration was found to increase near the central Amman city location, which is in the high vulnerable area. These high levels of $\mathrm{NO}_{3}^{-}$are probably attributed to leakage from old sewage water and from the present industrial wastewater infiltrated into the aquifer. Figure 16a shows the relationship between the concentration of $\mathrm{NO}_{3}^{-}$and the risk map of the study area and Figure 16b shows the location of samples with high $\mathrm{NO}_{3}^{-}$concentrations combined to the vulnerability map (Table 11).

Other samples with relatively low $\mathrm{NO}_{3}^{-}$concentrations can probably be related to soil characteristics and depth water table that allow insignificant $\mathrm{NO}_{3}^{-}$loading to enter the aquifers. 41 wells are located in the low risk zones with the highest $\mathrm{NO}_{3}^{-}$concentration of about $60 \mathrm{mg} / \mathrm{l}$, lowest of $5.8 \mathrm{mg} / \mathrm{l}$, and an average of about $31 \mathrm{mg} / \mathrm{l}$.

7 wells are situated in the moderate risk area, with the highest and lowest $\mathrm{NO}_{3}^{-}$levels of $61.8 \mathrm{mg} / \mathrm{l}$ and $3.5 \mathrm{mg} / \mathrm{l}$, respectively. The average concentration of $\mathrm{NO}_{3}^{-}$in the 
Table 11. Maximum, minimum, and average $\mathrm{NO}_{3}^{-}$concentrations of the risk map of the study area.

\begin{tabular}{lllll}
\hline & & Low Risk & Moderate Risk & High Risk \\
\hline & Max & 60.1 & 61.8 & 107.2 \\
$\mathrm{NO}_{3}^{-}(\mathrm{mg} / \mathrm{l})$ & Min & 5.8 & 3.5 & 81.1 \\
& Average & 31 & 42.1 & 97.7 \\
& {$[57]$ WHO (2011) } & 50 & & \\
& {$[58]$ Jordanian standard for drinking water (1997) 50} & & \\
\hline
\end{tabular}

(a)

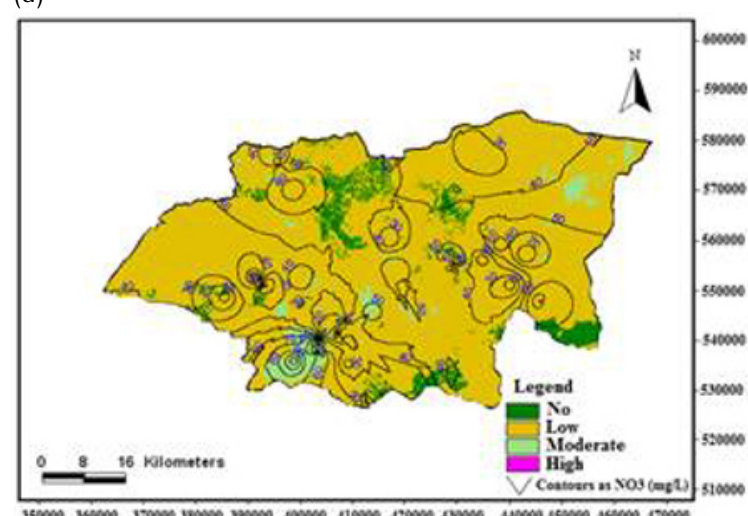

(b)

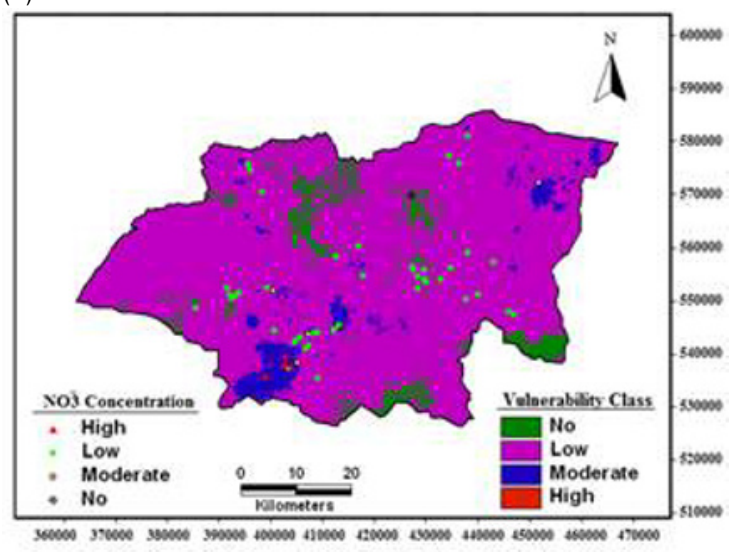

Figure 16. (a) Relationship map of $\mathrm{NO}_{3}^{-}$concentration with the risk map in the AZB; (b) Locations of samples with high NO-3 concentration on the vulnerability class's map.

moderately vulnerable zone is about $42.1 \mathrm{mg} / \mathrm{l}$.

\section{Conclusions}

The objective of this research is to evaluate the potential vulnerability of groundwater contamination in the AZB using the original and modified DRASTIC index applied in a GIS environment. Although the DRASTIC method usually gives satisfactory results in the evaluation of groundwater intrinsic vulnerability to contamination, it cannot be used for accurate assessment of the groundwater contamination risks. Therefore, it is necessary to calibrate and modify the original model in order to obtain more accurate results. Seven parameter maps were developed in a GIS environment to generate generic models and two parameters are added to modify the generic model (land use and lineament density maps). The DRASTIC vulnerability index values ranged between 34 and 299. Based on the hydrogeological field investigation and using a quintile classification method, these values were reclassified into four classes. The highly vulnerable areas constitute only $0.21 \%$ of the basin and are located in the central west of the AZB. Nitrate concentration of groundwater was evaluated for validation of the DRASTIC results. 54 groundwater samples have been analyzed for nitrate. In the low risk vulnerability zone, 41 groundwater wells showed an average nitrate concentration of $31 \mathrm{mg} / \mathrm{l}$ with highest values of $60 \mathrm{mg} / \mathrm{l}$. In the moderate pollution risk zone, 7 wells showed nitrate concentration ranging between 3.5 and $61.8 \mathrm{mg} / \mathrm{l}$. In the high risk zone, 4 wells found with nitrate concentration that varied from 81 to $107 \mathrm{mg} / \mathrm{l}$. Higher nitrate concentrations were observed in the high vulnerable area and are located closer to wastewater discharges.

\section{References}

[1] Villeneuve J., Banton O. and Lafrance P., A problematic approach for the groundwater vulnerability to contamination by pesticides: the VULPEST model. Ecological Modeling 51, 1990, 47-58

[2] Al-Adamant R., Foster I., and Baban S., Groundwater vulnerability and risk mapping for the Basaltic aquifer of the Azraq basin of Jordan using GIS, Remote sensing and DRASTIC, Applied Geography 23(4), 
2003, 303-324

[3] El-Naqa A., Aquifer Vulnerability Assessment Using the DRASTIC Model at Russeifa Landfill, Northeast Jordan, Environmental Geology 47(1), 2004, 51-62

[4] Al Kuisi M., El-Naqa A. and Hammouri N., Vulnerability mapping of shallow groundwater aquifer using SINTACS model in the Jordan Valley area, Jordan, Environmental Geology 50, 2006, 645-650

[5] Werz H. and Hötz H., Groundwater Risk Intensity Mapping in Semi-Arid Regions Using Optical Remote Sensing Data as an Additional Tool, Hydrogeology Journal 15(6), 2007, 1031-1049

[6] Hammouri N. and El-Naqa A., GIS based Hydrogeological Vulnerability Mapping of Groundwater Resources in Jerash Area-Jordan, Geofísica Internacional 47(2), 2008, 85-97

[7] Awawdeh M. and Jaradat R., Evaluation of Aquifers Vulnerability to Contamination in the Yarmouk Basin, Jordan, Based on DRASTIC Method, Jaradat Arabian Journal of Geosciences 3(3), 2010, 273-282

[8] Al-Rawabdeh A., Al-Ansari N. Al-Taani A., and Knutsson S., A GIS-Based Drastic Model for Assessing Aquifer Vulnerability in Amman-Zerqa Groundwater Basin, Jordan, J. Engineering 5(12), 2013, 490-504

[9] Shirazi S., Imran H., and Akib S., GIS-based DRASTIC method for groundwater vulnerability assessment: A review. Journal of Risk Research 15(8), 2012, 991-1011

[10] Al Hallaq A. and Elaish A., Assessment of aquifer vulnerability to contamination in Khan younis Governorate, Gaza Strip, Palestine, using the DRASTIC model within GIS environment. Arabian Journal of Geosciences 1, 2011, 1-15. doi: 10.1007/s12517-011-0284-9

[11] Shamrukh M., Corapcioglu M., Hassona, A. and Fayek A., Modeling the Effect of Chemical Fertilizers on Ground Water Quality in the Nile Valley Aquifer, Egypt. Ground Water 39 2001, 59-67

[12] Al-Hanbali A., and Kondoh A., Groundwater vulnerability assessment and evaluation of human activity impact (HAI) within the Dead Sea groundwater basin, Jordan. Hydrogeology Journal 16(3), 2008, 499-510

[13] Jasem H., Alraggad M., Assessing Groundwater Vulnerability in Azraq Basin Area by a Modified DRASTIC Index. Water Resource and Protection 2, 2010, 944-951

[14] DOS-Department of Statistics, Estimation of population by Governorate, Department of Statistics, Amman, 2004, www.dos.gov.jo/sdb_pop_e/ehsaat/ alsokan/1_2004.htm
[15] Awawdeh M. and Nawafleh A., A GIS-based EPIK model for assessing aquifer vulnerability in Irbid Governorate, North Jordan, Jordan Journal of civil Engineering 2(3), 2008

[16] Obeidat M., Ahmad F., Hammouri N., Massadeh F. and Athamneh F., Assessment of nitrate contamination of karst spring,Bani Kanana, northern Jordan. Revista Mexicana de Ciencias Geologicas 25, 2008, 426-437

[17] Lee SR., Lee D. H., Choi S. H., Kim W. Y., Lee $S$.G., Regional groundwater pollution susceptibility analysis using DRASTICsystem and lineament density. The Eighteen International ESRI User Conference, 1998

[18] Ferreira J. and Oliveira J., DRASTIC groundwater vulnerability mapping of Portugal. In Groundwater: an endangered resource Proceedings of theme $\mathrm{C}$ of the $27^{\text {th }}$ Congress of the International Association for Hydraulic Research, San Francisco, USA, 1997, 6

[19] American Public Health Association (APHA), Standard Methods for the Examination of Water and Wastewater, $18^{\text {th }}$ edition. Washington, DC: American Public Health Association, 1998

[20] WAJ - Water Authority of Jordan, WAJ Internal Files for Groundwater Basins in Jordan, 2006, http://www. mwi.gov.jo/sites/en-us

[21] MOA - Ministry of Agricultural, The soils of Jordan. National soil map and land use project. Hunting Technical Services Ltd. in association with Soil Survey and Land Research Centre. Vol. 2-level 2, main report. Ministry of Agricultural, Amman, Jordan. 1994

[22] Salameh L., Assessment of land use / cover changes in the Zerqa basin using remote sensing and Markove model, Faculty of graduate studies, University of Jordan, Amman.(unpublished M.Sc. thesis, 2006

[23] MacDonald M. and Partners in Cooperation with Hunting Geological Surveys Limited: East Bank Water Resources, East Bank Water Resources, Vol. 5, Ministry of Water and Irrigation, Amman, 1965, 512

[24] Salameh E. and Udluft P., The Hydrodynamic Pattern of the Central Part of Jordan, Geologisches Jahrbuch Reihe C 38, 1985, 39-55

[25] Bender F., Geology of Jordan, Contributions to the Regional Geology of the Earth, Supplementary Edition of Vol. 7, 196, Berline-Stuttgart (Gebruder Borntraeger), 1974

[26] Al Mahamid J., Integration of Water Resources of the Upper Aquifer in Amman-Zerqa Basin Based on Mathematical Modeling and GIS, Jordan, Ph.D. Thesis, University of Jordan, Amman, 2005 
[27] Napolitano P. and Fabbri A., Single-Parameter Sensitivity Analysis for Aquifer Vulnerability Assessment Using DRASTIC and SINTACS, Proceedings of the Vienna conference on Hydro GIS 96: Application of geographic information systems in hydrology and water resources management, IAHS 235, 1996, 559-566.

[28] Aller L., Bennett T., Lehr J. H., Petty R. J. and Hackett G., DRASTIC: A Standardized System for Evaluating Groundwater Pollution Potential Using Hydrogeologic Settings, US Environmental Protection Agency Report 600/2-87/035, US Environmental Protection Agency, Washington DC, 1987

[29] Vrba J. and Zoporozec A., Guidebook on mapping groundwater vulnerability. IAH International Contribution for Hydrogeology 16, 1994, Hannover7, Heise, 131

[30] US EPA (United States Environmental Protection Agency), (Handbook: Groundwater and Wellhead Protection. US EPA Report No. EPA/625/R-94/001, Washington, DC, 1994, 239

[31] Rosen. L., A study of the DRASTIC methodology with emphasis on Swedish conditions, Ground Water 32(2), 1994, 278-285

[32] Babiker M. Mohammed T. Hiyama and Kato K., A GIS-Based DRASTIC Model for Assessing Aquifer Vulnerability in Kakmigahara Heights, Gifu Prefecture, Central Japan, Science of the Total Environmental3 45(1-3), 2005, 127-140

[33] Anwar M., Prem C. and Rao V. B., Evaluation of Groundwater Potential of Musi River Catchment Using DRASTIC Index Model, In: Venkateshwar, B. R. Ram, M. K. Sarala C. S. and Raju, C. (Eds.), Proceedings of the International Conference on Hydrology and Watershed Management, B. S. Publishers, Hyderabad, 2003, 399-409

[34] Chandrashekhar H., Adiga S., Lakshminarayana V., Jagdeesha C. J. and Nataraj, C., A Case Study Using the Model 'DRASTIC' for Assessment of Groundwater Pollution Potential, Proceedings of the ISRS National Symposium on Remote Sensing Applications for Natural Resources, Indian Society of Remote Sensing, Bagalore, 19-21 June 1999, 414417

[35] Dixon B., Groundwater Vulnerability Mapping: A GIS and Fuzzy Rule Based Integrated Tool, Applied Geography, 2005, 25(4), 327-347.

[36] Margane M., Management and Protection and Sustainable Use of Groundwater and Soil Resources in the Arab Region, Volume 4: Guideline for Groundwater Vulnerability Mapping and Risk Assessment for Susceptibility of Groundwater
Resources to Contamination, Project No. 1996.2189.7, Federal Ministry for Economic Cooperation and Development, Bonn, 2003.

[37] Shahid S., A Study of Groundwater Pollution Vulnerability Using DRASTIC/GIS, west Bengal, India, Journal of Environmental Hydrology 8(11-12), 2000, 124

[38] Rundquist A., Peters D. Liping Rodekohr D., Ehrman R. and Murray G., State-Wide Groundwater Vulnerability Assessment in Nebraska Using the DRASTIC/GIS Model, Geo-Cartography International 6(2), 1991, 51-58

[39] O'Leary D., Freidman J., and Pohn H., Lineaments, linear, lineation-some proposed new standards for old terms. Geological Society of America Bulletin 87,1976, 1463-1469

[40] Lattman H. and Parizek R. Relationship between fracture traces and the occurrence of ground water in carbonate rocks. Journal of Hydrology 2, 1964, 73-91

[41] Mabee S. Hardcastle K. and Wise D., A method of collecting and analyzing lineaments for regionalscale fractured-bedrock aquifer studies, Groundwater 32(6), 1994, 884-894

[42] Hardcastle K., Photolineament factor: a new computer-aided method for remotely sensing the degree to which bedrock is fractured, Photogramm, Eng Remote Sensing 61(6), 1995, 739-747

[43] Magowe M. and Carr R., Relationship between lineaments and ground water occurrence in western Botswana, Ground Water 37(2), 1999, 282-286

[44] Fernandes D. and Rudolph A., The influence of Cenozoic tectonics on the groundwater production capacity of fractured zones: A case study in Sao Paulo, Brazil. Hydrogeology Journal 9, 2001, 151167

[45] MOCT (Ministry of Construction and Transportation) and KOWACO (Korea Water Resources Corporation), The handbook of drawing and management of hydrogeological map, MOCT, Korea, 1998, 456

[46] Merchant G., GIS-based groundwater pollution hazard assessment: a critical review of the DRASTC model, Photogramm Eng Remote Sensing 60, 1994, 1117-1127

[47] Secunda S., Collin M. and Melloul A. J., Groundwater Vulnerability Assessment Using a Composite Model Combining DRASTIC with Extensive Land Use in Israel's Sharon Region, Journal of Environmental Management 54(1), 1998, 39-57

[48] Chowdany V., Rao N. and Samara P., Decision support framework for assessment of non-point source pollution of groundwater in large irrigation projects, Agric Water Manag 75, 2005, 194-225 
[49] Mac Quarrie K., Sudicky E., and Roberston W., Numerical simulation of a fine-grained denitrification layer for removing septic system nitrate from shallow groundwater, J Hydrol 52, 2001, 29-55

[50] Postma D., Boesen C., Kristiansen H. and Larsen F., Nitrate reduction in an unconfined sandy aquifer: water chemistry, reduction processes and geochemical modeling. Water Resource Res 527, 1991, 45-202

[51] Baker L., Introduction to non-point source pollution in the United States and prospects for wetland use, Ecol Eng 1, 1992, 1-26

[52] Hubbard R. and Sheridan J., Nitrates in groundwater in the southeastern USA. In; Adriano, D., Iskadar A., Murarka I. editors. Contamination of groundwaters. Northwood, United Kingdom, Science Reviews, 1994, 45-303

[53] Ford M. and Tellam J., Source, type and extent of inorganic contamination within the Birmingham urban aquifer system, UK, J. Hydrol. 156, 1994, 101-135

[54] Lerner D., Yang Y., Barrett M. and Tellam J., Loading of non-agricultural nitrogen in urban groundwater. In: Ellis, J.B. (Ed.), Impacts of urban growth on surface and groundwater quality, IAHS publ. No. 259. IAHS Press, 1999, 117-123

[55] Seiler R., Combined use of $15 \mathrm{~N}$ and 180 of nitrate and $11 \mathrm{~B}$ to evaluate nitrate contamination in groundwater, Applied Geochemistry 20, 2005, 16261636

[56] Navarro M. Carbonell, Evaluation of groundwater contamination beneath an urban environment: The Besòs river basin (Barcelona, Spain). Journal of Environmental Management 85, 2007, 259-269

[57] World Health Organization (WHO), Drinking water quality-water, Background document for preparation of WHO Guidelines for drinking-water quality, Geneva, $4^{\text {th }}$ ed., 2011

[58] Jordanian Drinking Water Standards JS286/1997, http://ocid.nacse.org/rewab/docs/JS286_Drinking_ Water_Standards_1997_en.pdf 